\title{
PENGEMBANGAN PETUNJUK PRAKTIKUM BIOLOGI PADA MATERI JAMUR DENGAN POLA PEMBERDAYAAN BERPIKIR MELALUI PERTANYAAN (STUDI KASUS DI KELAS X.3 SMA MUHAMMADIYAH 1 METROTAHUN PELAJARAN
} (2013/2014)

\author{
Astri Anggraini \\ Pendidikan Biologi FKIP Universitas Muhammadiyah Metro \\ E-mail: astrianggraini59@yahoo.com
}

\begin{abstract}
The purpose of this research is to produce practical guidance with patterns of thinking empowerment by questioning. This researchdevelopment starting from the definition phase, the planning phase, and the development phase. The development phase includes three steps, namely validation by expert teacher and two lecturers, product revision, and produk testing. Validation expert is testing materials and the quality of the results obtained $100 \%$ with a very high category. Readability level got result $>60 \%$ with ten indicators of getting high category. Aplicatibility level got result> $60 \%$ with two indicators of gettinh veri high category and eight indicators of getting high category. Practice guidancehas beendevelopedin accordancewith thecriteria ofgoodpracticeguidance. Practice guidance developed has advantages which can develop students' critical thinking skills, but this guide also has the disadvantage that only limited one material is Mushroom material.
\end{abstract}

KataKunci:Penelitiandanpengembangan, petunjuk praktikum, berpikir melalui pertanyaan.

Biologi merupakan bagian dari Ilmu Pengetahuan Alam (IPA), yang tidak hanya berisi tentang pemahaman konsep-konsep dan prinsip-prinsip saja, tetapi IPA juga berkaitan dengan bagaimana menemukan suatu konsep yang dilakukan secara sistematis dan ilmiah. Proses pembelajaran tidak hanya berpatokan dengan pemahaman siswa akan suatu konsep namun juga melihat kemampuan siswa dalam menemukan, hal ini menunjukkan bahwa biologi tidak jauh dari kegiatan praktikum, hal ini sesuai dengan pernyataan Salirawati (2010:5) mengungkapkan "Penggunaan buku petunjuk praktikum sangat besar peranannya dalam proses pembelajaran IPA, sehingga seolah-olah buku ini menjadi 'buku sakti' ketika seorang guru akan melakasanakan praktikum di laboratorium".Kegiatan praktikum yang dilaksanakan di sekolah melatih siswa untuk melakukan suatu kerja ilmiah sesuai dengan pendapat Hasrudin (2012) menjelaskan bahwa: "Membiasakan siswa belajar melalui proses kerja ilmiah, selain dapat melatih detail keterampilan ilmiah dan kerja sistematis, dapat pula membentuk pola berpikir siswa secara ilmiah" Kegiatan praktikum dibutuhkan dalam proses pembelajaran. Proses praktikum membutuhkan suatu petunjuk yang digunakan untuk memandu siswa untuk melakukan praktikum sesuai dengan yang ditetapkan oleh petunjuk praktikum yang sudah ada.

Data yang di dapatkan ketika prasurvei adalah petunjuk yang 
digunakan belum bisa mengkondisikan siswa pada saat praktikum, karena masih ada siswa yang bertanya tentang bagaimana melakukan praktikum, bagaimana cara yang harus dilakukan. Petunjuk praktikum pada materi Jamur juga didapatkan dari buku paket yang tersedia dalam bentuk yang masih sederhana. Melihat permasalahan yang seperti ini, maka penulis bermaksud mengembangkan petunjuk praktikum dengan Pola PBMP pada materi Jamur.

Penelitian ini mengembangkan petunjuk praktikum dengan menggunakan pola pemberdayaan berpikir melalui pertanyaan (PBMP), karena pola PBMP ini sangat cocok dengan proses praktikum yang akan lebih baik apabila dilengkapi dengan jalinan pertanyaan. Pertanyaanpertanyaan tersebut dapat membuat siswa akan lebih memahami materi yang dipraktikumkan. Menggunakan pola PBMP dapat membantu siswa mencapai tujuan pembelajaran, dengan memakai pola PBMP juga dapat membentuk pembelajaran yang baru dengan mengidentifikasi pengetahuan berdasarkan pertanyaan, sesuai dengan yang dinyatakan oleh Fithrotin (2011:151) menyimpulkan "penerapan TEQ (Thinking Empowerment by Questioning) berpengaruh positif terhadap keterampilan berpikir kritis siswa berpengaruh positif terhadap hasil belajar siswa. Petunjuk praktikum yang dikembangkan memiliki format sesuai dengan pola PBMP yaitu sediakan, lakukan, pikirkan, evaluasi dan arahan, hal ini telah disampaikan oleh Corebima (2007:8) menyatakan "Systematically, TEQ structureswere Introduction, Prepare, Do (Discuss, Team Work /Demonstration andReflect), Think, Assessment, and Direction. Pengembangan ini bertujuan untuk menghasilkan petunjuk praktikum dengan pola PBMP yang memiliki kualitas yang baik yang diharapkan dapat menjadi pedoman bagi siswa dalam melaksanakan praktikum.

\section{METODE}

Penelitian ini menggunakan metode pengambangan dengan menggunakan model pengembangan 4$\mathrm{D}$, model pengembangan 4-D disarankan oleh Thiagarajan, Semmel dan Semmel (dalam Trianto, 2011:189). Model 4-D terdiri dari 4 tahap yaitu define, design, develop dan disseminate. Dalam penelitian ini hanya berhenti pada tahan ke 3 yaitu tahap pengembangan (develop), karena keterbatasan waktu serta biaya sehingga penelitian ini hanya berhenti pada tahap pengembangan. Proses validasi oleh ahli dilaksanakan pada tanggal 14 November 2013, 22 November 2013 dan 23 November 2013. Uji coba siswa dilaksanakan di kelas X.3 SMA Muhammadiyah 1 Metro pada tanggal 28 November 2013 dan 30 November 2013. Desain uji coba produk petunjuk praktikum dengan pola PBMP dapat dilihat pada gambar 1 . 


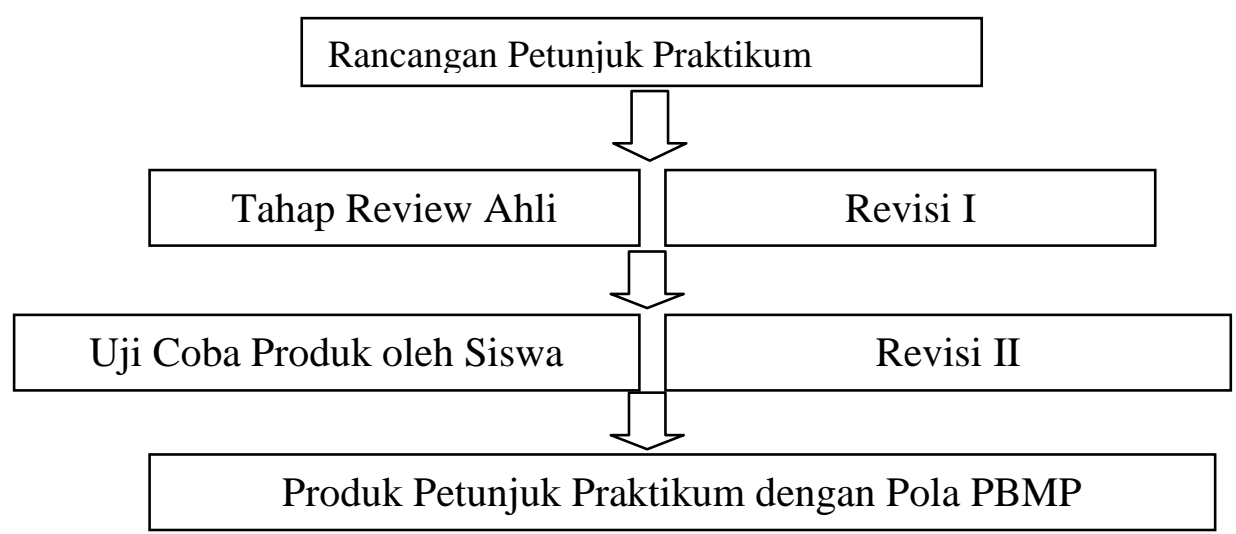

Gambar 1. Desain Uji Coba Produk Petunjuk Praktikum Dengan Pola PBMP

\section{Hasil Pengujian oleh Ahli}

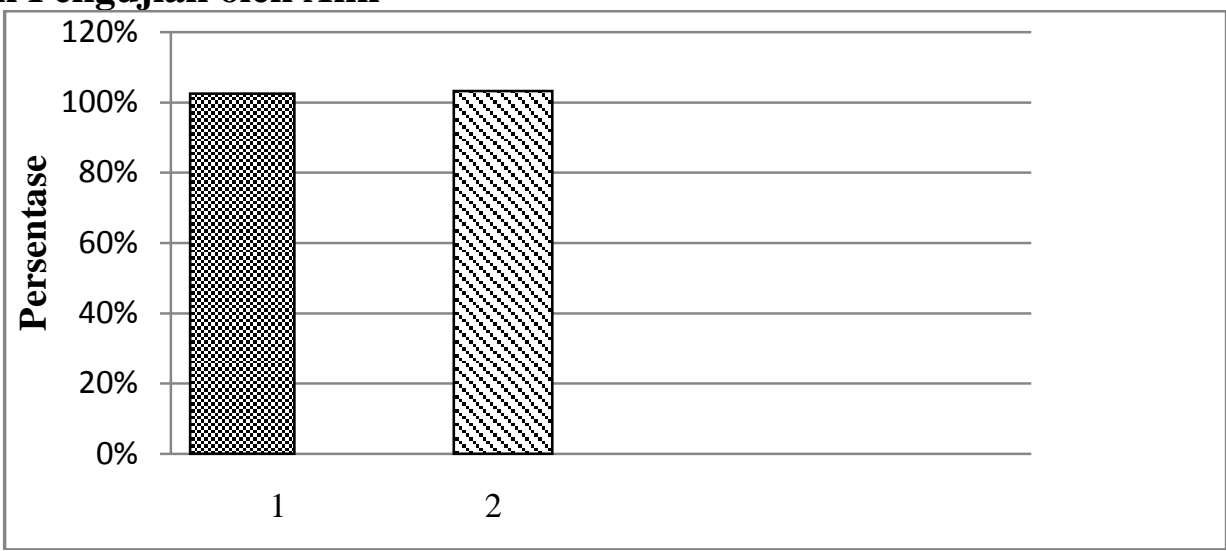

Gambar 2. Diagram Hasil Pengujian Ahli

Keterangan:

1: Uji Isi Materi.

2: Uji Kualitas Petunjuk Praktikum.

HASIL

Serangkaian pengembangan petunjuk praktikum pada materi Jamur dengan Pola PBMP telah dilakakukan dan menghasilkan data tentang penilaian ahli dari segi materi dan kualitas petunjuk praktikum, hasil angket keterbacaan dan hasil angket keterlaksanaan yang kemudian ditafsirkan pada tafsiran Arikunto (2006)
Berdasarkan gambar 2 diketahui bahwa penilaian untuk isi materi yang terdapat pada petunjuk praktikum $100 \%$ setuju yang masuk dalam kriteria sangat tinggi yang artinya sudah layak untuk digunakan. Penilaian untuk kualitas petunjuk praktikum $100 \%$ setuju yang masuk dalam kriteria $100 \%$ yang artinya petunjuk praktikum sudah layak digunakan pada pelaksanaan praktikum. 


\section{Hasil Data Angket Keterbacaan Petunjuk Praktikum}

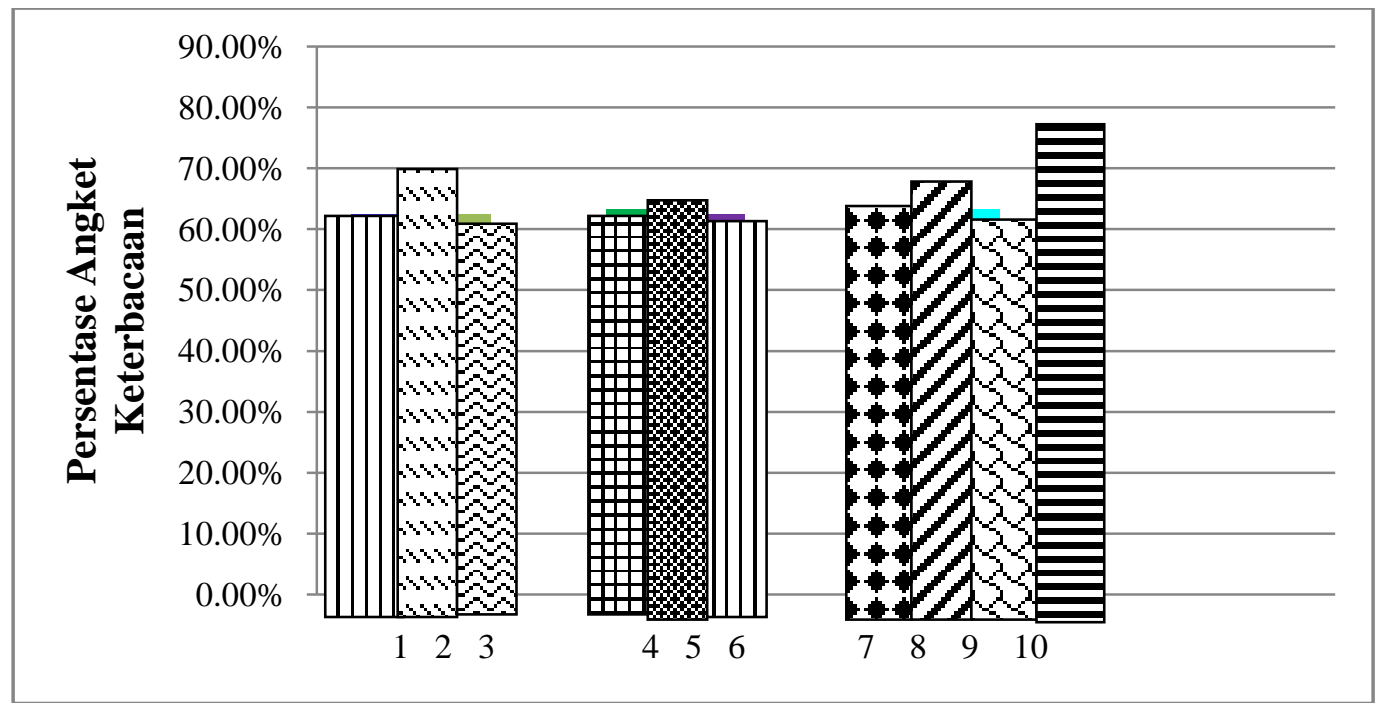

Gambar 3. Diagram Hasil Data Angket Keterbacaan Petunjuk Praktikum Keterangan:

1: Ukuran Huruf.

2: Pemilihan Kata.

3: Bentuk dan Penyajian.

4: Dasar Teori yang Terdapat pada Petunjuk.

5: Isi atau Pesan.

Berdasarkan gambar 3 diketahui bahwa ukuran huruf pada petunjuk praktikum 62,5\%. Pemilihan kata pada petunjuk praktikum 72,7\%, bentuk dan penyajian petunjuk praktikum $62,5 \%$. Dasar teori yang terdapat pada petunjuk praktikum $63,5 \%$, isi atau pesan yang terdapat dalam
6: Alat dan Bahan.

7: Runtutnya Langkah Kerja.

8: Pertanyaan untuk Didiskusikan.

9: Lembar Hasil Pengamatan.

10: KejelasanArahanSetelah Melakukan Praktikum.

petunjuk praktikum 68,8\%. Penjelasan alat dan bahan yang digunakan pada saat praktikum $62,5 \%$, runtutnya langkah kerja pada petunjuk praktikum 63,5\%. Pertanyaan-pertanyaan untuk didiskusikan $68,8 \%$, dan kejelasan arahan yang diberikan setelah praktikum $78,8 \%$. 


\section{Hasil Data Angket Keterlaksanaan Petunjuk Praktikum}

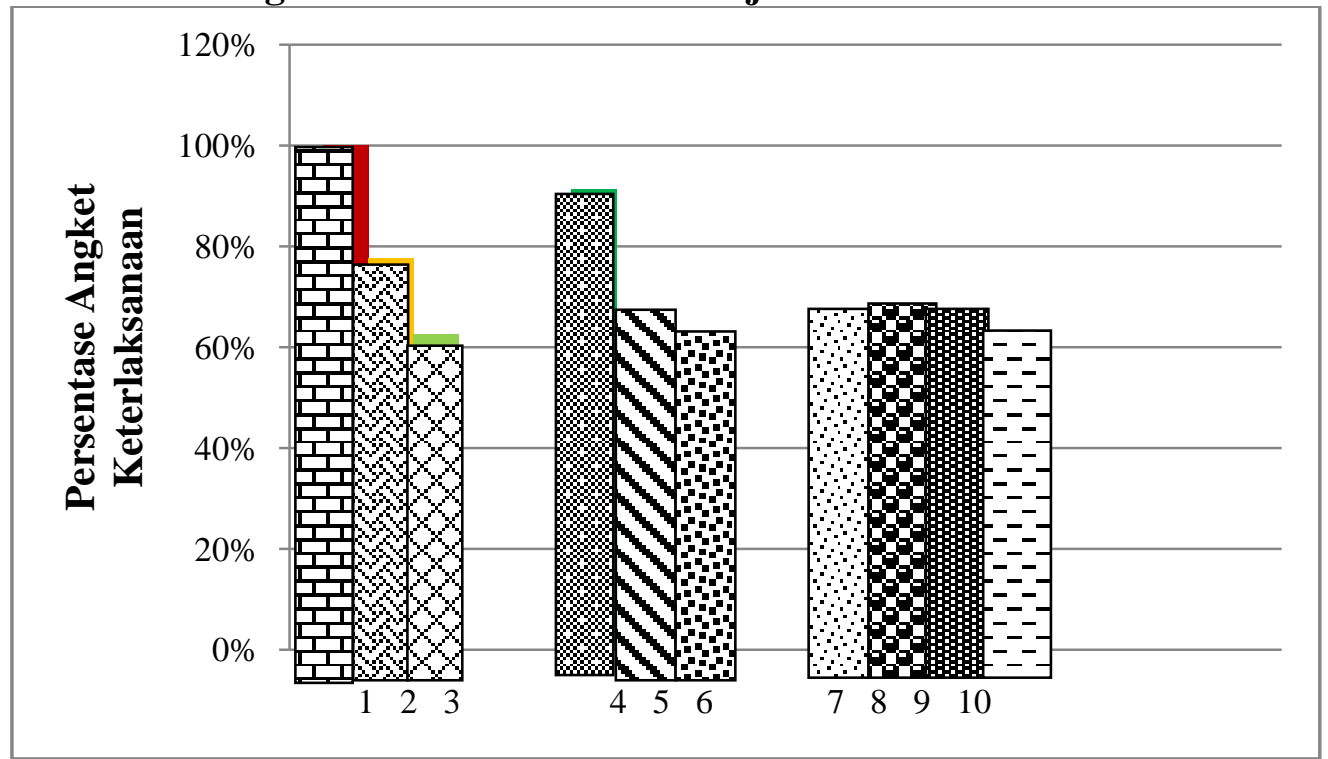

\section{Gambar 4. Diagram Hasil Data Angket Keterlaksanaan Petunjuk Praktikum}

Keterangan:

1: Persiapan Alat dan Bahan.

6: Pengisian Tabel Hasil Pengamatan.

2: Kemampuan Melakukan Praktikum Sesuai dengan Langkah Kerja.

7: Penyelesaian Pertanyaan-Pertanyaandalam Petunjuk.

3: Pelaksanaan Praktikum.

4: Pembagian Tugas dalam Kelompok.

5:Ketelitian dalam

Menemukan.

8: Mendiskusikan Hasil Praktikum.

9: Kemampuan untuk Menyimpulkan Hasil Praktikum.

10: Pendapat Mengenai Praktikum Menggunakan Petunjuk Praktikum dengan pola PBMP.

Berdasarkan gambar 4 diketahui bahwa persiapan alat dan bahan yang digunakan pada saat praktikum didapatkan hasil 100\%, kemampuan melakukan praktikum sesuai dengan langkah kerja 77,6\%. Pelaksanaan praktikum $62,5 \%$, pembagian tugas dalam kelompok 91,4\%. Ketelitian dalam menemukan $66,1 \%$, pengisian tabel hasil pengamatan $62,5 \%$. Penyelesaian pertanyaan-pertanyaan dalam petunjuk praktikum $66,7 \%$, kemampuan untuk menyimpulkan hasik praktikum $66,1 \%$ dan pendapat siswa mengenai praktikum menngunakan petunjuk praktikum dengan pola PBMP 62,5\%.

\section{PEMBAHASAN}

Petunjuk praktikum dengan pola PBMP sebagai hasil pengembangan telah melewati tahap pengujian oleh 3 ahli dan uji coba oleh siswa, maka revisi produk dapat dilakukan. Petunjuk praktikum akan direvisi apabila persentase dari indikator $\leq 60 \%$, dan tidak direvisi apabila persentase dari indikator > $60 \%$.

Berdasarkan gambar 2, 3 dan 4 dapat dilihat bahwa petunjuk praktikum dengan pola PBMP yang sudah dikembangkan tidak ada yang direvisi, dikarenakan dari ketiga penilaian 
didapatkan hasil > 60\%. Komponen petunjuk praktikum yang berhasil dikembangkan sudah sesuai dengan komponen petunjuk praktikum yang ideal untuk digunakan dalam proses praktikum. Komponen petunjuk praktikum yang ideal menurut Farikhayati (2010) yaitu "dalam petunjuk praktikum tercantum judul praktikum, alat dan bahan, langkah kerja, pertanyaan-pertanyaan yang akan mngungkap pengetahuan siswa". Dalam petunjuk praktikum yang sudah dikembangkan ini juga terdapat penjelasan akan penulisan laporan, format penulisan laporan dijelaskan pada bagian akhir sehingga siswa dapat dengan mudah menyelesaikan laporan yang harus dikerjakan setelah pelaksanaan praktikum. Petunjuk praktikum dengan pola PBMP ini sudah terbukti dapat membimbing siswa dalam proses praktikum dan petunjuk praktikum dengan pola PBMP ini dapat memacu siswa untuk berpikir yang dipandu oleh kegiatan pengamatan pada saat praktikum, peningkatan kemampuan berpikir siswa dengan menggunkan pola PBMP sudah dibuktikan oleh Fatimah (2010:12) bahwa "penggunaan pola PBMP juga dapat meningkatkan kemampuan berpikir kritis siswa". Petunjuk praktikum dengan pola PBMP yang berhasil dikembangkan ini dapat menggantikan petunjuk praktikum yang sebelumnya yang peneliti anggap belum ideal untuk digunakan, dengan penggunaan petunjuk praktikum dengan pola PBMP ini proses praktikum siswa dapat berjalan dengan lancar hal ini dinyatakan oleh Utomo (2011:7), "pelaksanaan praktikum akan berjalan lancar apabila didukung oleh petunjuk praktikum yang memadai dan mudah dimengerti oleh siswa". Secara keseluruhan petunjuk praktikum dengan pola PBMP yang sudah berhasil dikembangkan sudah layak digunakan dalam proses praktikum, dan menjadi pedoman siswa dalam proses praktikum, sesuai dengan Keputusan Menteri Pendidikan Nasional Nomor: 36/D/O/2001 "Petunjuk praktikum adalah pedoman pelaksanaan praktikum yang berisi tata cara persiapan,pelaksanaan, analisis data dan pelaporan. Pedoman tersebut disusun dan ditulis olehkelompok staf pengajar yang menangani praktikum tersebut dan mengikuti kaidah tulisanilmiah".Layaknya petunjuk praktikum yang dikembangkan dilihat dari segi materi, kualitas, keterbacaan dan keterlaksanaan. Secara keseluruhan petunjuk praktikum dengan pola PBMP yang sudah berhasil dikembangkan sudah layak digunakan dalam proses praktikum. Petunjuk praktikum yang ideal atau baik akan mudah untuk dimengerti siswa sehingga dalam proses praktikum siswa tidak akan bingung dengan apa yang harus ia lakukan hal ini sesuai dengan pernyataan Rahayuningsih (2005:24) mengemukakan "Petunjuk/perintah pelaksanaan kegiatan harus jelas dan tidakmembingungkan"karena "seorang anak didik hanya mempraktikkan apa yang tertulis dalam petunjuk praktikum" Salirawati (2009:3), sehingga petunjuk praktikum yang sudah ideal ini dijadikan suatu pedoman bagi siswa dalam praktikum.

\section{KESIMPULAN dan SARAN Kesimpulan}

Petunjuk praktikum yang berhasil dikembangkan sudah memenuhi kriteria petunjuk praktikum yang baik menurut Farikhayati (2010), selain itu petunjuk praktikum yang dihasilkan dapat dijadikan alat evaluasi pembelajaran sesuai dengan yang dinyatakan oleh Pasaribu (2012). Petunjuk praktikum yang dihasilkan 
dapat dipahami oleh siswa dan mempermudah siswa dalam proses praktikum sehingga dapat memperlancar proses praktikum secara keseluruhan. Petunjuk praktikum yang dihasilkan tidak ada yang direvisi hal ini menandakan bahwa peyunjuk praktikum dengan pola PBMP sudah layak untuk digunakan dalam proses praktikum. Kelebihan dari petunjuk praktikum dengan pola PBMP diantaranya petunjuk praktikum memiliki komponen yang tersusun secara sistematis, menggunakan pola PBMP memberi peluang siswa untuk mengembangkan kemampuan berpikir kritis. Kekurangan dari petunjuk praktikum yang dikembangkan yaitu petunjuk praktikum yang dikembangkan hanya terbatas pada materi Jamur.

\section{Saran}

Petunjuk praktikum dengan pola PBMP ini dapat digunakan oleh semua siswa kelas $X$, pengembangan petunjuk praktikum ini tidak hanya pada materi Jamur saja namun untuk materi-materi yang lain. Pengembangan petunjuk praktikum dapat dilakukan dibeberapa sekolah tidak hanya satu sekolah saja.

\section{DAFTAR PUSTAKA}

Arikunto, Suharsimi. 2006. ProsedurPenelitian (Suatu Pendekatan Praktik). Jakarta: Rineka Cipta.

Corebima, A. Duran. 2007. Learning Strategis Having Bigger Potency To Emprove Thinking Skill And Concep Of Lowyer Academy Student. (online) http://conference.crpp.nie.edu.sg/ 2007/paper/papers/COG483.pdf. Diakses 18 Februari 2013.

Farikhayati. 2009. Pengembangan Buku Petunjuk Kimia untuk
SMP/MTs Kelas VII Berdasarkan Kurikulum Tingkat Satuan Pendidikan (KTSP). Skripsi. Yogyakarta: Program Studi Pendidikan Kimia Fakultas Sains dan Teknologi Universitas Islam Negeri Sunan Kalijaga.

Fatimah, Anis Nurul. 2010. Peningkatan Kemampuan

Berpikir Kritis Siswa Melalui Penerapan Pola PBMP Pada Pokok Bahasan Fotosiintesis Siswa Kelas VIII E SMP N 5 Surakarta Tahun Pelajarn 2010/2011. Jurnal Pendidikan Biologi. FKIP Universitas Sebelas Maret.

Fithrotin, Titik, Suprapto Nadi. 2011. The Role of Thinking Empewerment By Question (TEQ) Learning Physic Of Light On The Subject Matter of Critical Thinking Skill Student Junior High School 6 Surabaya. E.jurnal UnesaVolume 1 No.1 hlm 151.

Hasrudin. 2012. Analisis Pelaksanaan Praktikum Biologi Dan Permasalahanny Di SMA N Sekabupaten Karo. Jurnal Tabularasa PPS UNIMED Vol. 9, No 1.

Keputusan Menteri Pendidikan Nasional. 2001. Petunjuk Pelaksanaan Penilaian Angka Kredit Jabatan Dosen. Jakarta: Kemendiknas.

Trianto. 2011. Mendesain Model Pembelajaran Inovatif-Progresif. Jakarta: Kencana.

Pasaribu, Rapika. 2007. Pengembangan Dan Standarisasi Buku Penuntun Praktikum Kimia SMA Kelas XI Semester II Sesuai Dengan Tuntutan KTSP. Skripsi. Medan: Program Studi Pendidikan Kimia Universitas Medan.

Rahayuningsih, Edia, Djoko Dwiyanto. 2005. Pembelajaran 
Laboratorium. Yogyakarta: Pusat pengembangan Pendidikan Universitas Gajah Mada

Salirawati. 2009. Manajemen Laboratorium Kimia/ IPA. Makalah Disampaikan Pada Kegiatan Pembinaan MGMP Bagi Guru SMA Dan SMK Angkatan III Se-Kabupaten, Sleman: 23 Juli 2009.

Salirawati. 2010. Pelatihan Pengembangan Praktikum IPA Berbasis Lingkungan. Artikel Jurnal INOTEK hlm 5.

Utomo, M Pranjoto. 2011. Adaptasi Pelaksanaan Praktikum Kimia Negara OECD. Makalah disampaikan Pada PPM Unggulan berjudul Adaptasi Kurikulum Kimia SMA Bertaraf Internasional terhadap Kurikulum dari Negara OECD, di FMIPA UNY: 4 Juni 2011. 